\title{
Concept and Implementation of Centralized Management in the Management and Development of Muhammadiyah Business Charities (Study of Management and Development of AUM in PCM Cileungsi)
}

\author{
$1^{\text {st }}$ Firmansyah Azharul \\ Department of Mechanical \\ Engineering, Sekolah Tinggi \\ Teknologi Muhammadiyah \\ Cileungsi, \\ Cileungsi, Bogor, Indonesia 16820 \\ firmansyah.azharul@gmail.com
}

\author{
$2^{\text {nd }}$ Mustopa Idris \\ Department of Industrial \\ Engineering, Sekolah Tinggi \\ Teknologi Muhammadiyah \\ Cileungsi \\ Cileungsi, Bogor, Indonesia 16820
}

\begin{abstract}
The concept of good management in managing the Muhammadiyah business charity is important to do, because the task of managing and developing a charity business is not only the task of the head of AUM but it is the job of the Persyarikatan leadership where the business charity was founded. The reality in the field shows that there is a highly developed business charity of Muhammadiyah and there is also a business charity that has not yet developed, even though the existence of the business charity is still a shelter at the Branch or Branch Management level. Therefore this research was conducted to find out the concept and implementation of centralized management as one of the efforts in managing and developing Muhammadiyah business charities so that it could become a model for Persyarikatan both at the Branch and Branch Leadership level. Centralized management carried out by the head of the Muhammadiyah Cileungsi branch proved to be effective in helping the process of managing and developing the Muhammadiyah business charity, within 34 years since it was first established, the head of the Muhammadiyah Cileungsi branch has had 28 business charities in the religious, educational, economic and social fields. there are 7 centralized management concepts are applied and developed, including: 1) centralized management in management and leadership, 2) centralized management in finance, 3) centralized management in HR, 4) centralized management in planning and auditing, 5) centralized management in facilities and infrastructure, 6) centralized management in purchasing, and 7) centralized management in economics. If the seven concepts can be implemented at every level of the company, either the branch, branch, regional or regional level, there is no longer the term developing business charity and underdeveloped business charity.
\end{abstract}

Keywords-Management, Development, Muhammadiyah Business Charities

\section{INTRODUCTION}

$\mathrm{Bi}$-verbal preaching al things or preaching with actions carried out by Muhammadiyah has the same function and position as the preaching bi-lisal al-maqal, the difference is only in the embodiment of the concept of preaching carried out. The bi-verbal preaching of al-maqal is carried out in the form of routine recitals and religious studies, while the preaching done by Muhammadiyah is manifested in various forms of business charity, both in the fields of education, health, economics and in the social field, to That attention to the concept of management and development management of Muhammadiyah Business Charities must be done seriously, because Muhammadiyah Business Charities become the leading means of preaching to achieve the vision and mission of Muhammadiyah that has been aspired.

With various charitable businesses owned by Muhammadiyah, the management of management in each of the charitable endeavors must be a serious concern, because the role of Muhammadiyah's charitable endeavors is very large for the continuation of missionary preaching, both pre-bi-oral pre-al-maqal and bi-oral pre-al preaching.

The Management of Muhammadiyah's Business Charities at each level of the Persyarikatan Leadership is indeed different, depending on the policies of the Chairperson where the Charity Business was founded. The problem that often arises is usually the management and 
development of Muhammadiyah Business Charities is only centered on the Muhammadiyah Business Charity Leaders themselves, Persyarikatan Leaders starting from Branch and Branch Leaders tend to only think about how to establish a new business charity, when the management, development and managerial processes are fully surrendered. to the leaders of business charities, so that the development of business charities sometimes does not go hand in hand, there are business charities that are so large, there are also business charities that are so small that even there are business charities that even pay salaries for teachers and employees are still lacking, let alone to meet the needs of facilities and infrastructure in its business charity.

The results of research conducted by Andhini Hudha Anggarasari and Milah Nur Kamilah showed that the organizational management process that began with planning had never been done thoroughly between the leadership and all Muhammadiyah residents. There are no plans for short, medium to long term plans. The research shows that the leadership of the company does not have a good management direction in managing and developing a charity business, so that the planning carried out is conditional and temporary.

Therefore, the concept of good management is needed, which can make the development of Muhammadiyah business charities can go hand in hand with other business charities, so there is no longer the term developing business charity and undeveloped business charity.

The facts in the field show that there are still many Muhammadiyah schools that are not yet qualified due to the lack of independence of the school causing high dependency of the school both on the government and outside parties (especially educational personnel, funds, facilities and infrastructure to school management), the weakening of the militancy of the management force causes a lack of enthusiasm independence in managing and developing Muhammadiyah business charities[1].

Dependence on the government or outside parties can be overcome if the Persyarikatan can maximize the role and function of other charitable businesses that are within the internal environment of Muhammadiyah itself, through the application of good and directed management. Good management will facilitate the realization of organizational goals, because with the management of the effectiveness and effectiveness of the elements of management (men, money, materials, machines and methods) can be maximally improved, given Islamic teachings, the implementation of any activity must be carried out neatly, right, orderly, and orderly.

\section{METHOD}

The research used is qualitative, research conducted by collecting descriptive data that describe the research object in depth. The approach used in this study is an empirical juridical approach that is an approach that is done by looking at the reality that exists in practice in the field. The source of the data used in this study was sourced from secondary data and primary data derived from direct observations and interviews with the founders, advisers, leaders of the PCM Cileungsi and several staff who were directly involved in the management of centralized management. Analysis of the data used is descriptive analysis of research that seeks to tell the solution of existing problems based on data, it also presents data, analyzes, interprets, and objectively describes the data obtained.

\section{RESULTS AND DISCUSSION}

A. Centralized areas of organizational management and leadership

Centralized organizational management[2]and leadership, which focuses all organizational policies and decisions at the highest level[3], in this case it is at the level of leadership of the Muhammadiyah Association. Also, the leadership of the company as the highest leader has the authority in deciding policies that will be applied to the charity he has. Such as determining the target of admission of new students to AUM education, determining the amount of education costs, determining the leadership in each AUM both the head of AUM, deputy head, head of department or head of study program and so forth. This is done so that all charity businesses owned by the company can implement all the policies that have been made.

However, although the centralization of organizational management and leadership is centered on company policies, the business charity still has its autonomy in developing and carrying out its business charitable activities, as long as it does not deviate from the decisions and provisions that have been made by the company.

\section{B. Centralized financial sector}

The centralization of the financial sector was the first centralization field carried out by the head of the Muhammadiyah Cileungsi branch, this field concentrated all revenue receipts from all business charity units into corporate income. This includes the receipt of zakat, infaq, shadaqah and waqf (ZISWAF) funds managed entirely by the head of the Muhammadiyah Cileungsi branch. The business charity unit which is centralized in finance is the business charity unit in the fields of religion, education, health, economic and social fields, including:

- Charitable Educational Enterprises As The Largest Source Of Income.

- Process flow of financial receipts and disbursements.

- Financial income. 


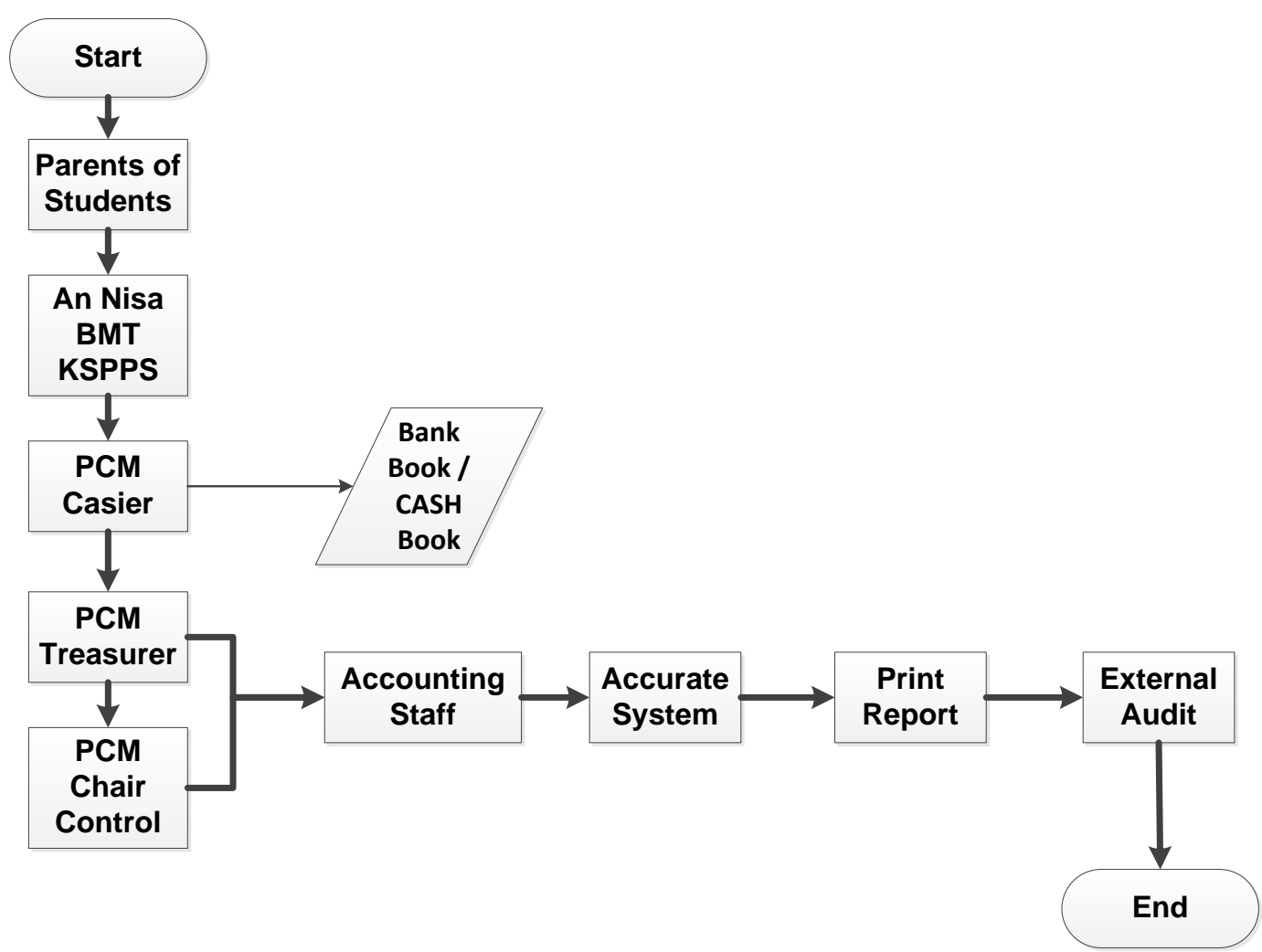

Fig. 1. Flowchart of the PCM Cileungsi Financial Reception.

- Financial expenditure.

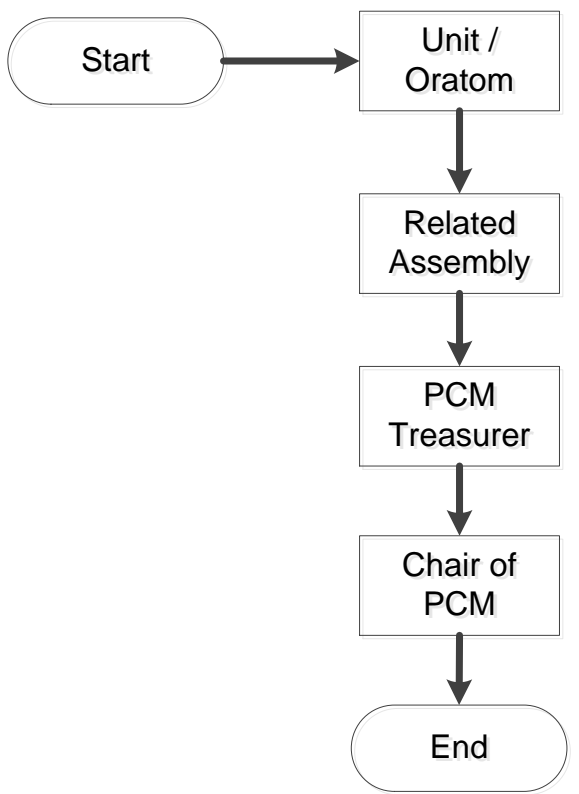

Fig. 2. Flow of Financial Filing Process

\section{Centralized human resources}

Centralization of the field of human resources is centralized[3]conducted by PCM Cileungsi by centralizing all human resource management (HR) under the control of the company.

There is a special section that handles HR management[4]in the environment of the Muhammadiyah Cileungsi Society which is part of human resources. This section has the task of selecting prospective employees assisted by several assemblies (Tabligh and Tarjih
Assembly and Dikdasmen assemblies), accepting employees, assessing employee performance in one period, assigning employees to one AUM and rolling employees to several AUMs. Therefore the status of the employees at PCM Cileungsi is not in the name of AUM employees, but the employees of the Muhammadiyah Cileungsi Branch Manager.

D. Centralized planning and audit

Centralized planning and auditing are centralized[5]in making an income plan[6]and budget expenditures or 
expenses in 1 year, as well as conducting audits[5]of the revenues and expenditures so that there are no irregularities in the use of the budget. In the centralization of the planning and auditing fields each business charity unit and each autonomous organization[7](orthom) compiled an annual revenue and expenditure (RAPB) budget plan accompanied by the relevant assemblies as the person in charge of implementing the activities both in the business charity unit and in the orthom. after the RAPB has been prepared by each AUM then the chair of the assembly submits the results of its preparation to the branch leadership and will be ratified during the leadership plenary meeting.

E. Centralization of facilities and infrastructure

Centralization of facilities and infrastructure is centralized[8]in concentrating all the facilities and infrastructure needs to the Muhammadiyah organization, in this case it is the duty and responsibility of the purchasing and infrastructure section of the PCM Cileungsi.

- Procurement of PCM Cileungsi facilities.

- $\quad$ Procurement of PCM Cileungsi infrastructure.

F. Centralized purchasing field

The centralization of the purchasing sector is part of the centralization of the facilities and infrastructure sector[9], where one of the tasks and responsibilities of the infrastructure section is to purchase goods according to the request submitted by AUM and the purchase of the goods is carried out by the purchasing department with the approval of the facilities and infrastructure section of the Cileungsi PCM.

The purchasing department is in charge:

- Purchase of all the needs of business charity unit facilities

- Make purchases of building material needs that have been collaborated with material stores.

- Make purchases of clothing raw material requirements for making student uniforms and is done by the convection unit.

\section{G. Centralized economic field}

Centralized economic sector is a centralization that focuses all economic activities and activities[10]AUM is under the management of the Muhammadiyah Association in this case PCM.The economic assembly as the organizer of the AUM in the field of economics coordinates all economic activities within each AUM, then centralizes all its activities under the control of the economic assembly.

\section{CONCLUSION}

Based on the research conducted, it can be seen that the management concept applied and developed by the Branch Manager of Muhammadiyah Cileungsi is the concept of centralized management, where all decisions and policies in the management and development of business charities are centered at the top management level, which in this case is at the level of leadership leadership. 7 concepts of centralized management are applied and developed, including: 1) centralized management in management and leadership, 2) centralized management in finance, 3) centralized management in HR, 4) centralized management in planning and auditing, 5) centralized management in facilities and infrastructure, 6) centralized management in purchasing, and 7) centralized management in economics. If the seven concepts can be implemented at every level of the company, either at the branch, branch, regional or regional level, there is no longer the term developing business charity and underdeveloped business charity, because centralized management is in principle applied as part of the effort to supervise charity owned business, so that its setbacks and development can be known by the company and the company can determine the direction of the business charity policy precisely in the process of its development.

\section{ACKNOWLEDGMENT}

Thank you to the Muhammadiyah Research and Development Institute for PP which has funded your research in 2019-2020.

\section{REFERENCES}

[1] M. J. Susilo, "Kajian kemandirian sekolah di amal usaha muhammadiyah," Pros. Semin. Nas. Pendidik. Berkemanjuan dan Menggembirakan, pp. 625-633, 2016.

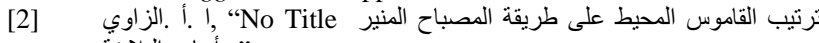
".

[3] N. F. Qalase, "delivery: A case of Bedford Hospital , Department of Health , Province of the," no. January, 2014.

[4] J. Dooney, "How Centralized and Decentralized HR Structures Influence HR Metrics," Soc. Hum. Resour. Manag., pp. 1-10, 2016.

[5] W. F. Sorte, "Assessing the efficiency of centralised public procurement in the Brazilian ICT sector," Int. J. Procure. Manag., vol. 6, no. 1, pp. 58-75, 2013.

[6] EY, "Centralized operations," no. February, 2014.

[7] M. Hegazy and M. Elnahass, "An Analysis of Multi-Location Audit Risk Factors and the Improvement of the Audit Process: an Empirical Study," J. Econ. Eng., vol. 3, no. 1, pp. 35-49, 2012.

[8] P. D. H. Hines, S. Blumsack, and M. Schläpfer, "Centralized versus Decentralized Infrastructure Networks," no. October, 2015 .

[9] K. S. Aboelazm and A. Afandy, "Centralization and decentralization of public procurement: Analysis for the role of General Authority for Governmental Services (GAGS) in Egypt," J. Adv. Manag. Res., vol. 16, no. 3, pp. 262-276, 2019.

[10] P. Ong and S. Fritzen, Decentralization in Developing Countries, no. 581. 2007. 